\title{
EVALUATION OF COMBINE HARVESTER OPERATION COSTS IN DIFFERENT WORKING CONDITIONS
}

\author{
Jiri Masek ${ }^{1}$, Petr Novak ${ }^{1}$ Algirdas Jasinskas ${ }^{2}$ \\ ${ }^{1}$ Czech University of Life Sciences Prague; ${ }^{2}$ Aleksandras Stulginskis University, Lithuania \\ masekj@tf.czu.cz, algirdas.jasinskas@asu.lt
}

\begin{abstract}
Combine harvesters have a very important task in grain crop harvesting. Combine harvesters must fulfil lot of technological requirements regarding the field conditions, crop type, as well as the quality performance and optimal costs. The problem is that it is the main harvesting technology of cereals in the world and it has seasonal character of work, which has to be done in a relatively short period of time with adequate costs. The aim of this paper is an evaluation of the economic parameters of combine harvesters in different working conditions. The study is based on exact cost analysis of combine harvesters of New Holland brand by different ages and different concepts of threshing. Data were collected during all working seasons of the combine. In average, there is a data set from 10 seasons. In evaluation there were 9 machines NH CR 9080 and another 9 machines NH CX 8080. The working parameters evaluated are fuel consumption and operational costs. Performance of the machines was measured as harvested per hectare per day and per whole season. Costs are calculated as fixed and variable. The maintenance and service costs, and fuel consumption per hectare harvested are deeply analyzed. The result shows that the effect of the cost analysis depends on the terms of annual performance of the machine. There is 2.11 per hectare difference in the fuel consumption between tangential and axial threshing systems. A special result of this study is evidence of the spare part costs for every machine and setting up the individual coefficient of repairs.
\end{abstract}

Keywords: combine harvesters, costs, harvesting, performance, coefficient of repairs.

\section{Introduction}

In terms of modern agriculture combine harvesters occupy an important place for several reasons. The first is, of course, a good and early harvest of crops while maintaining grain quality parameters, especially of food wheat and malting barley, as well as in conditions similar to the last few summers, when there were frequent and heavy rainfalls, and it was necessary to shorten the harvest time of cereals. Another important reason is the continuously improving work efficiency of modern combine harvesters. Many farmers and agricultural enterprises invested to the purchasing the high performance combines to maximize threshing performance to achieve high quality grain and minimum losses [1]. This trend is due to the shortage of the labor force in the agriculture sector.

Self-propelled harvesting combines are the key machines to realize performance in grain harvesting [2], and we can say that it is the main harvesting technology of cereals in the world. Nowadays modern combine harvesters are versatile machines designed to highest efficiently harvest a wide range of grain crops from the field. Modern combines can harvest more than 80 kinds of grain crops [3]. Harvesting of grain crops is a very important task among all working activities in agriculture. Construction or design of combine harvesters must satisfy certain technical and technological requirements according to the crop, weather, environmental and field conditions and postharvesting technologies [4].

There are two main types of combine harvesters - conventional (tangential flow) combines and rotary (axial-flow) combines [3]. A conventional combine is characterized by its tangential threshing system with one or two threshing drums and straw walkers as a grain separator, while a rotary combine has an axial-flow integrated threshing and separating system [5].

The problem from the service point of view could be a seasonal character of work in a very short period of time, 5-7 weeks depending on the wheatear. We can observe a trend in increasing feedrate of combines. It is due to two main reasons - increasing the production of grain crops and optimization of the harvesting time. The price of combine harvesters is quite high - it is possible to say that these are one of most expensive machines in agriculture. From the perspective of the machinery operator monitoring of costs and its structure is very important. It allows finding the right moment for making a decision to sell it and buy a new one or prepare the machine for general repair. For economic efficiency it is recommended to provide the highest possible performance with the lowest possible operating costs [6]. It means to harvest as much as possible area during one season to reduce the fixed 
costs of the machine as much as possible. Fuel consumption has the highest influence on the amount of variable costs [7].

The aim of this paper is evaluation of eighteen randomly chosen self- propelled combine harvesters New Holland operated in the regions Ústecký and Středočeský in the Czech Republic.

\section{Materials and methods}

Two groups of randomly chosen combine harvesters were evaluated. The first group represented conventional (tangential flow) combines with 9 combine harvesters NH CX 8080 and in the second group there were 9 combine harvesters NH CR 9080 with axial-flow of material (Fig. 1). These combine harvesters worked in different companies and in different field conditions. Data were collected from operational records and from the board computer of each machine every year after closing the harvesting season.
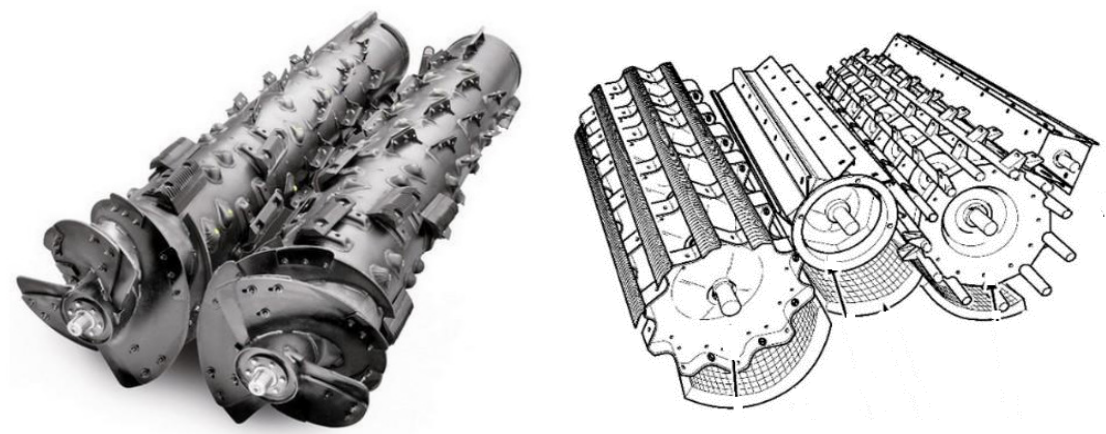

Fig. 1. Working mechanism of combine harvester line CR (left) and CX (right) [8]

All combine harvesters were put into the service from 2006 till 2014. The oldest machine in the group was 10 years old and the youngest was 3 years old (Tab. 1). Data were collected on long term bases form since 2006 till 2016 season. For every group of combine harvesters in a total 63 seasons were counted - it is done due to differences in the age of machines in the group. Minimum are 3 harvesting seasons per combine harvester. All machines were equipped with a $9 \mathrm{~m}$ width header.

The data used for evaluation are as follows: engine and trashing hours, total used fuel, total harvested area, costs of spare parts, filters, fluids, amount of service labour hours, cost of labour, frequency of mechanical, electrical, hydraulic, maintenance interventions/service operations.

Calculation of the coefficient of repairs for machines is based on calculation of total costs of repairs and spare parts during technical life and the comparison with the price of the machine. The coefficient tells how much the user pays for service and maintenance of the machine during its technical life.

Total cost $C_{\text {Total }}$ expended on the machine is calculated as a sum of fixed and variable costs.

$$
C_{\text {Total }}=C_{F}+C_{V} \text {. }
$$

Fixed costs $\mathrm{C}_{\mathrm{F}}$ (formula 2) based on:

- depreciation $\operatorname{cost} \mathrm{C}_{\mathrm{D}}$;

- insurance cost $\mathrm{C}_{\mathrm{I}}$;

- garage place cost $\mathrm{C}_{\mathrm{G}}$.

$$
C_{F}=C_{D}+C_{I}+C_{G}
$$

Variable costs $\mathrm{C}_{\mathrm{V}}$ (formula 3 ) based on:

- fuel costs $\mathrm{C}_{\mathrm{FC}}$;

- costs of maintenance, repairs and servicing $\mathrm{C}_{\mathrm{RS}}$;

- labour costs for operators of the combine harvester $\mathrm{C}_{\mathrm{LO}}$.

$$
C_{\text {Total }}=C_{F C}+C_{R S}+C_{L O} \text {. }
$$

The costs of maintenance, repair and service $C_{R S}$ were read from the company accounting system and from the service partner. 
Overview of combine parameters in evaluation

Table 1

\begin{tabular}{|c|c|c|c|c|c|c|c|}
\hline Combine & $\begin{array}{c}\text { Total } \\
\text { Working } \\
\text { Engine, } \\
\text { Mth }\end{array}$ & $\begin{array}{c}\text { Total } \\
\text { Working } \\
\text { Threshing, } \\
\text { Mth }\end{array}$ & $\begin{array}{c}\text { Working } \\
\text { threshing, } \\
\text { Mth·year-1 }\end{array}$ & $\begin{array}{c}\text { Total } \\
\text { harvested } \\
\text { area, ha }\end{array}$ & $\begin{array}{c}\text { Total fuel } \\
\text { consumption, } \\
\mathbf{l}\end{array}$ & $\begin{array}{c}\text { Av. fuel } \\
\text { consumption, } \\
\text { 1·ha- }\end{array}$ & $\begin{array}{c}\text { Seasons } \\
\text { number, } \\
\text { year }\end{array}$ \\
\hline CR 980_1 & 3606 & 2611 & 237.4 & 7395 & 110608 & 15.0 & 11 \\
\hline CR 9080_2 & 2066 & 1556 & 155.6 & 4092 & 65916 & 16.1 & 10 \\
\hline CR 9080_3 & 2821 & 2030 & 225.6 & 6327 & 111191 & 17.6 & 9 \\
\hline CR 9080_4 & 1754 & 1357 & 193.9 & 4322 & 82438 & 19.1 & 8 \\
\hline CR 9080_5 & 2190 & 1550 & 221.4 & 4889 & 86878 & 17.8 & 7 \\
\hline CR 9080_6 & 1270 & 993 & 165.5 & 2972 & 57764 & 19.4 & 6 \\
\hline CR 9080_7 & 979 & 745 & 149.0 & 2346 & 38602 & 16.5 & 5 \\
\hline CR 9080_8 & 1100 & 768 & 192.0 & 2280 & 46160 & 20.2 & 4 \\
\hline CR 9080_9 & 697 & 485 & 161.7 & 1533 & 23838 & 15.5 & 3 \\
\hline CX 860_1 & 2714 & 2162 & 196.6 & 6124 & 85651 & 14.0 & 11 \\
\hline CX 8080_2 & 2424 & 1766 & 176.6 & 4379 & 71523 & 16.3 & 10 \\
\hline CX 8080_3 & 2568 & 1771 & 196.8 & 4406 & 71395 & 16.2 & 9 \\
\hline CX 8080_4 & 1326 & 987 & 169.6 & 3062 & 44687 & 14.6 & 8 \\
\hline CX 8080_5 & 1572 & 1159 & 165.6 & 3185 & 51844 & 16.3 & 7 \\
\hline CX 8080_6 & 1392 & 1082 & 180.3 & 2972 & 45557 & 15.3 & 6 \\
\hline CX 8080_7 & 859 & 668 & 133.6 & 2087 & 27953 & 13.4 & 5 \\
\hline CX 8080_8 & 6888 & 556 & 139.0 & 1653 & 22434 & 13.6 & 4 \\
\hline CX 8080_9 & 487 & 365 & 121.7 & 1085 & 14876 & 13.7 & 3 \\
\hline
\end{tabular}

Calculation of the coefficient of repairs $\left(C O_{R P}\right)$ is based on the sale price of the combine harvester $\left(P_{T O T}\right)$ and the costs of maintenance, repairs and servicing $\left(C_{R S}\right)$ :

$$
C O_{R P}=\frac{P_{T O T}}{C_{R S}} .
$$

\section{Results and discussion}

Evaluation of the variable costs was focused on maintenance, service and spare parts for every machine in the observed group. For evaluation of the service work the number of interventions to different groups of the combine mechanisms and systems was counted - mechanical, electrical and hydraulic and general maintenance before the harvest season. The results are shown in Fig. 2 and Fig. 3. It is possible to say that there is no difference in the number of interventions between the CR and CX combine lines. Most of interventions were done in mechanical way - $57 \%$ of all service work, the next system is electrical (17-21\%) and only $8 \%$ of interventions were done in hydraulics.

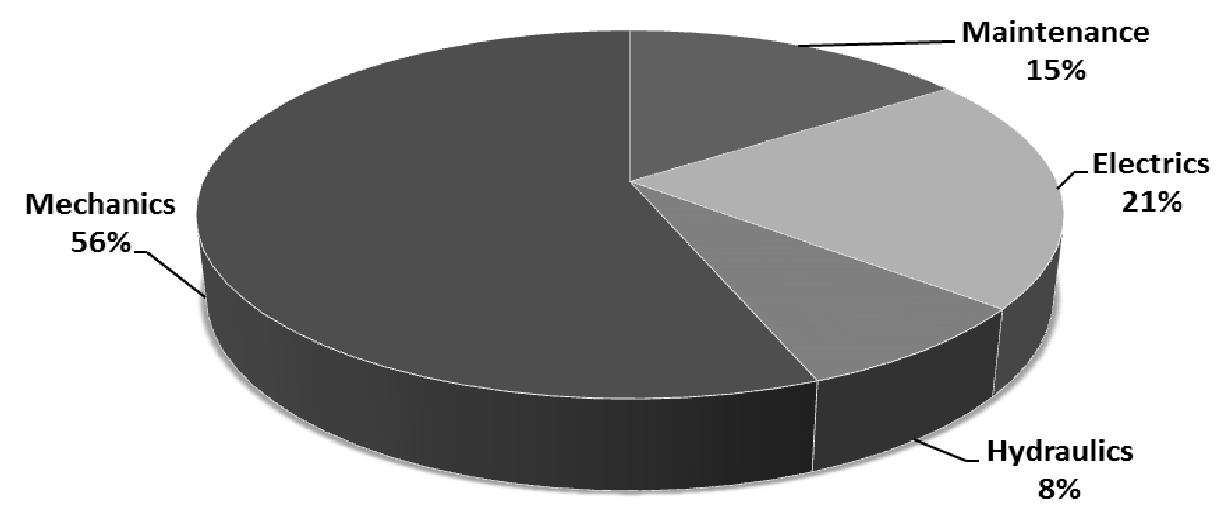

Fig. 2. Average share of service interventions in group of NH CR 9090 combine harvesters 


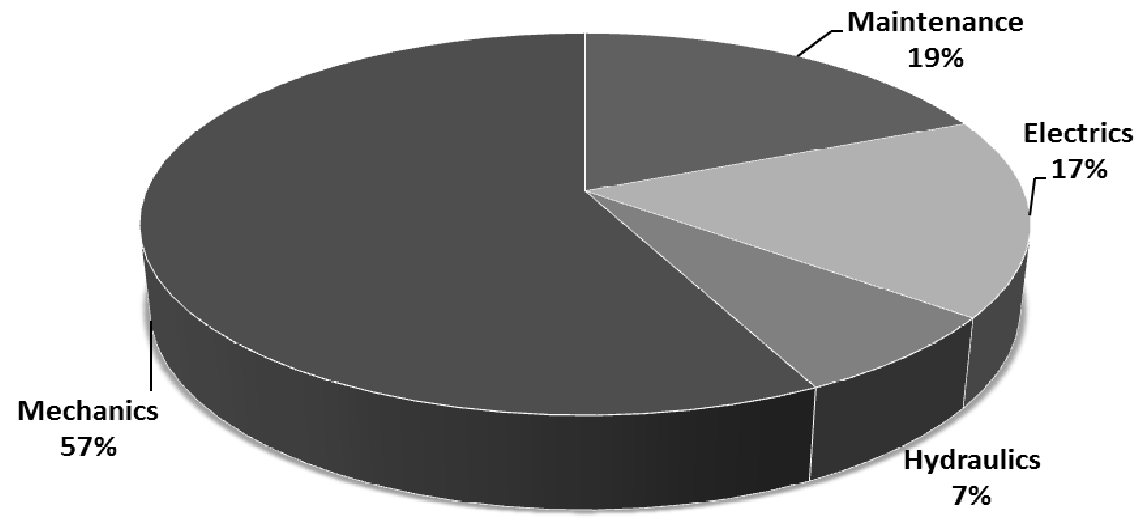

Fig. 3. Average share of service interventions in group of NH CX 8080 combine harvesters

Evaluation of fuel consumption during harvest shows results, which confirm the experiments of other authors $[6 ; 7 ; 9]$. It means that the axial flow combine harvester has higher average fuel consumption per 1 ha harvested. In the evaluated group of combine harvesters the average diesel consumption 17.2 1. ha ${ }^{-1}$ was calculated for the axial flow model NH CR 9080 and the average diesel consumption $15.1 \mathrm{l} \cdot \mathrm{ha}^{-1}$ for the tangential flow model NH CX 8080. For evaluation STATISTICA software, tools ANOVA was used. There is significant difference between the tangential and axial threshing mechanism in fuel consumption on the chosen level of relevance $(\alpha=0.05)$. Average consumption is calculated for total 63 seasons (Fig. 4).

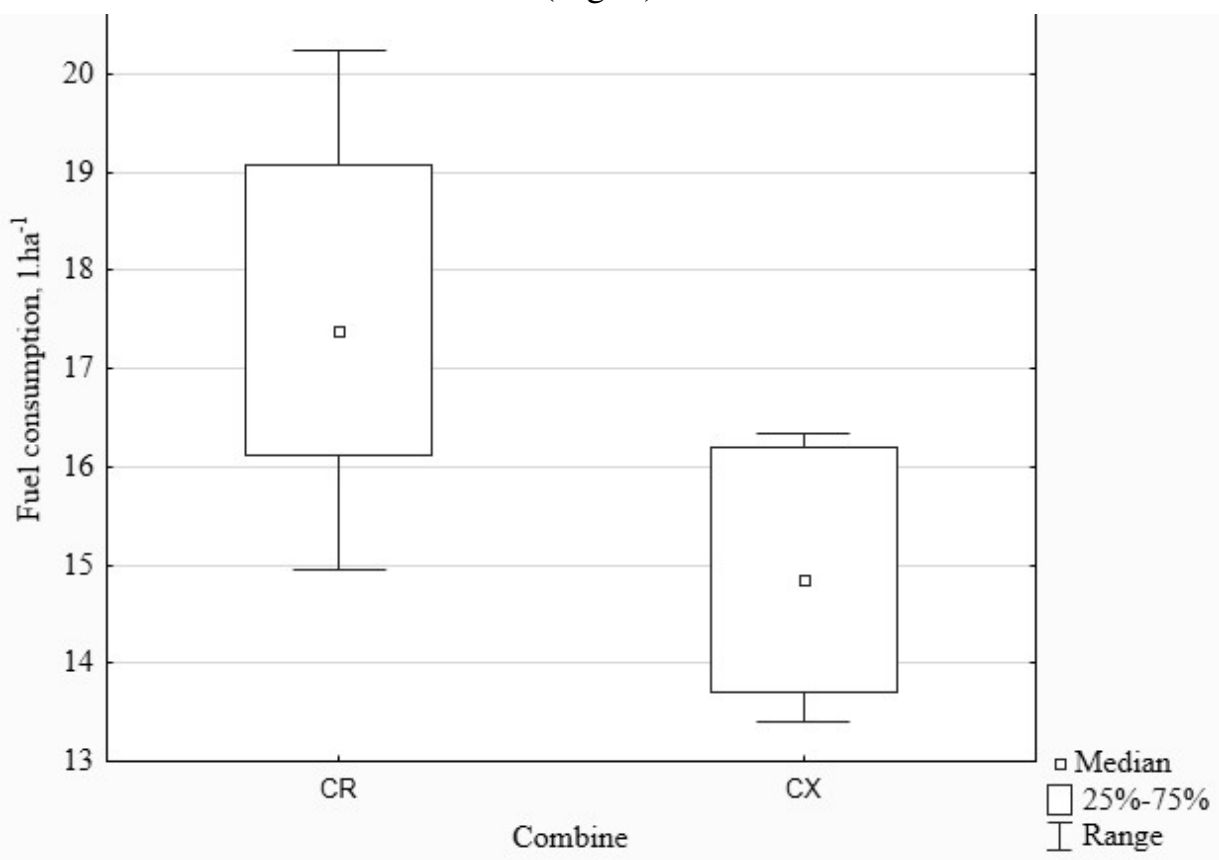

Fig. 4. Results of ANOVA evaluation of fuel consumption

In that situation we can generalize the working condition, because there was similar representation of harvested crops and a similar share of time with or without chopping the straw on the field directly by harvesting.

Evaluation and determination of the coefficient of repairs is very interesting. All service, maintenance and spare part costs were calculated during all seasons of utilization of every machine and thereafter compared with the specific machine sale price. Total service costs were calculated from the data of all working seasons of the machines included for the evaluation. The share of service interventions is in the same composition for both groups of machines (Fig. 2 and Fig. 3), but the whole coefficient of repairs is a little higher for the combine harvester with axial flow of material - line CR 9090. 
Total values $C O_{R P}$ in the compared group of the machines are set on 0,135 for CR machines and 0,103 for CX machines. There is no significant difference (Fig. 5) between the CR and CX model line on the chosen level of relevance $(\alpha=0.05)$. It means that during the technical life is necessary to invest $13.5 \%$ (by CR) or $10.3 \%$ (by CX) from the sale price of the machine to the spare parts and service work (accident damages excluded). In the data set of values in different seasons we can observe changes in the service costs. Especially there is big step up between the $7^{\text {th }}$ and $8^{\text {th }}$ season in the amount of the service work and the spare parts used. It could be one of the reasons for the decision to bay a new combine harvester due to increasing service costs.

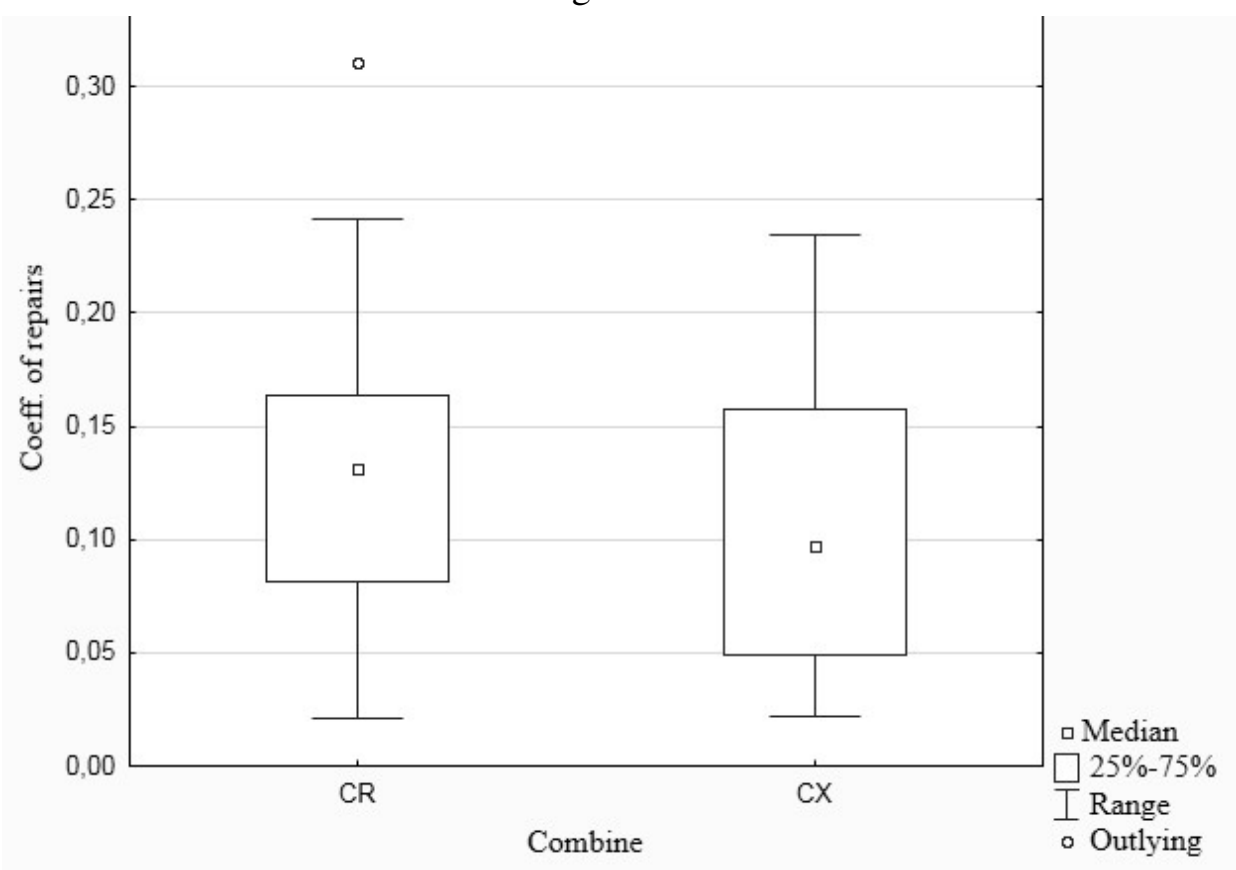

Fig. 5. Results of ANOVA evaluation of coefficient of repairs

\section{Conclusions}

1. The structure of service and maintenance interventions for both groups of different combine harvester lines is on the same level, compared to solving problems in mechanics, electrics and hydraulic systems.

2. Machines with axial flow of material during the threshing process have higher fuel consumption in the evaluated group of machines. But material throughput during the threshing process and performance of axial combine harvesters is higher compared to combines with conventional system of threshing.

3. The values of $C O_{R P}$ in the evaluated group of machines are without significant differences between the CX and CR machines. Average value for the CX line is 0.103 and for the CR line it is 0.135 . Approximately $10-13 \%$ of the combine harvesters' price has been spent for service and repairs during technical life of the selected group of the combine harvesters.

\section{Acknowledgement}

Thanks for cooperation to all farmers and companies to help us with collecting the data.

\section{References}

1. Kutzbach H.D., Quick G.R. Harvesters and threshers. In CIGR Handbook of Agricultural Engineering. Vol. III. Plant Production Engineering, ed. B.A. Stout, St. Joseph, MI: American Society of Agricultural Engineers, 1999, pp. 311-347..

2. Herlitzius T., Mueller H., Kranke G., Wittig H., Wolf J. Concept Study of a Self Propelled Harvester versus a Modular System. Proceedings of International Conference "Landtechnik AgEng 2011”, November 11-12, Hannover, Germany, pp. 69-75. 
3. Miu P. Combine Harvesters - Theory, Modeling and Design. CRC Press, 2016. 437 p. ISBN 9781-4822-8237-5.

4. Steponavicius D., Petkecius S., Domeika R. Determination of rational values of inclination angles of straw walker sections, Engineering for Rural Development 2011, pp. 76-81.

5. Kumhala F. et al. Zemedelská technika - stroje a technologie pro rostlinnou výrobu. First edition. Prague: CULS Prague, 2007. 426 p. ISBN 978-80-213-1701-7. (in Czech)

6. Benes L., Novak P., Masek J., Petrasek S. John Deere combine harvesters fuel consumption and operation costs. Proceedings of International Conference "Engineering for Rural Development 2014”, May 29-30, 2014, Jelgava, Latvia, pp. 13-17.

7. Spokas L., Steponavicius D. Fuel consumption during cereal and rape harvesting and methods of its reduction. Journal of Food Agriculture \& Environment, vol. 9, No. 3-4, 2011, pp. 257-263.

8. Agrotec. [online] [10.2.2017] Available at: http://www.eagrotec.cz/sklizeci-mlaticky.

9. Císař V. Evaluation of New Holland combine harvesters in Czech Republic conditions. MSc diploma thesis. FE CULS Prague. 2017, 104 p. (in Czech) 